\title{
Recalibrating the Classic Models of Mediation: Former Leaders and Hybrid Personality-Network Driven Initiatives in the Venezuela Crisis*
}

\author{
Recalibrando los modelos clásicos de mediación: exlíderes políticos e \\ iniciativas de redes de personalidades híbridas en la crisis de Venezuela
}

\author{
ANDREW F. COOPER \\ University of Waterloo, Canada
}

\begin{abstract}
This article examines the shift away from the classic models of mediation to a hybrid personality-network approach with specific reference to the Venezuela crisis. Instead of third-party mediators possessing formal organizational standing and resources, the focus of this recalibrated model is placed on voluntary initiatives driven by ex- leaders. Of particular interest is the set of activities via Jimmy Carter and the former Prime Minister of Spain, Jose Luis Rodríguez Zapatero. As witnessed by the Venezuela crisis, space is available for engagement combining empowered agency and network partnerships. While Carter and Rodríguez Zapatero were in the forefront of building and implementing this team effort, however, they faced as individuals most of the risks attached to implementing the recalibrated model.
\end{abstract}

Keywords: Venezuela, mediation, former leaders, International Organizations, networked partnerships.

\begin{abstract}
RESUMEN
Este artículo examina el cambio de los modelos clásicos de mediación a un enfoque híbrido de redes de personalidad con referencia específica a la crisis de Venezuela. En lugar de poner el énfasis en los mediadores externos, los cuales poseen recursos y una posición organizacional formal, este modelo se enfoca en las iniciativas voluntarias impulsadas por ex líderes políticos de renombre. De particular interés son las actividades realizadas por el expresidente norteamericano Jimmy Carter y el expresidente del Gobierno de España, José Luis Rodríguez Zapatero. Como lo atestigua la crisis de Venezuela, hay espacio para acciones simultáneas entre asociaciones de redes y agencias autorizadas. Si bien Carter y Rodríguez Zapatero estuvieron a la vanguardia de la construcción e implementación de este esfuerzo de equipo, se enfrentaron como individuos a la mayoría de los riesgos asociados a la implementación del modelo recalibrado.
\end{abstract}

Palabras clave: Venezuela, mediación, exlíderes, organizaciones internacionales, asociaciones en red.

This article has been supported by the Social Sciences and Humanities Research Council of Canada (SSHRC) [Insight grant number: 435-2015-1357]. This article was originally presented as papers at the Barcelona, LASA and the Quito ISA/FLACSO Quito conferences in May/July 2018, organized by Thomas Legler and Sean W Burges. The author would like to thank the participants at those earlier panels for their valuable comments, as well as the anonymous reviewers and editorial team at the Revista de Ciencia Política for their comments work and support in refining the work. 


\section{INTRODUCTION: THE SHIFT AWAY FROM THE CLASSIC MODELS}

The modalities of mediation, that is to say, processes animated by third parties designed to contribute to peaceful settlement of disputes, have undergone considerable changes from the traditional models well-rehearsed in the academic literature (Touval and Zartman 1985; Bercovitch 1996). The conventional assumption is that these third party or "outside" mediators acted on behalf of specific nation states or International Organizations (IOs). On the one hand, mediators were commonly high-level representations of powerful states - most notably the United States (U.S.) - and so tightly embedded at the core of what has been termed "club" diplomacy (Cooper 2004; Heine 2013), The classical cases relate to the activities of Henry Kissinger mediating from 1973 to 1975 in the Middle East (Pruitt 1981), or Alexander Haig mediating in the case of the Malvinas/Falklands crisis during 1981 and 1982 (Goshko 1982). On the other hand, there are numerous illustrations of the United Nations (UN) acting as a mediator, whether through the efforts of the UN Secretary General (UNSG) or the UNSG's "good offices" through an envoy or special representative, with a sharp rise in activity through the 1980s and 1990s (Iran-Iraq, Cambodia, El Salvador, Guatemala, to name just a few) (Crocker, Hampson and Aall 1999; United Nations 2011). Although operating outside the bounds of standard state -centric or club style mediation, this type of engagement is explicitly anchored in a single, lead organization. In either variant, mediation as agency possessed some firm foundation in the form of formal standing and resources, as well as an organizational interest in the specific crisis (Bercovitch and Gartner 2009: 22).

As exampled by the experience of mediation in Venezuela, the fixed location of these classic models is severely challenged amidst the complexities of protracted crises in the $21^{\text {st }}$ century, Despite the risks of engagement, not only has the range of meditators expanded, with space created for actors beyond the dominance of representatives of a single powerful state or privileged IO. But the relationship between different components within an expanded and diversified form of mediation has become more fluid and complex. As Ahtisaari and Rintakoski aptly put it, from a more generalized perspective: "Mediation is an increasingly crowded and unregulated field, characterized by multiple and varied initiatives, sometimes competitive ones" (Ahtisaari and Rintakoski 2013: 337).

Yet, notwithstanding these major shifts in the nature of mediation, two long-standing debates about mediators remain relevant. At odds with the image of an accentuated multiplicity of actors, the nature and impact of key individual mediators has continued to attract attention. If less likely to be representatives from powerful states - notably the US - or under the primacy of the UN than in the past, the enlarged span of mediators has meant that the question of who the specific actors taking up this type of role has increased as well. 
Of particular interest to this article is the accentuated role of ex-leaders, individuals notwithstanding a variety of distinctive backgrounds, who share common attributes: notably the duality of experience as former heads of national government combined with a set of concerted global activities after moving out of office (Cooper 2014). As witnessed by the prominent role of Jimmy Carter and the former Prime Minister of Spain, Jose Luis Rodríguez Zapatero, in mediation initiatives with respect to Venezuela, these individuals are both similar and different from other mediators coming from backgrounds beyond the classic models associated with representatives of a single powerful state of the primacy of the UN. Such variant actors have been located for example in religious bodies whether the Vatican/Holy See or as in the Mozambique case, the Community of Sant'Egidio (Bartoli 1999), or alternatively located in civil society organizations, including the involvement of International Alert in the Sierra Leone crisis. In common with these other actors, the mediatory activity performed by the former leaders are done on what Bercovitch and Garner term a "voluntary" basis with no fixed or stable connection to a state or IO apparatus or set of national or organizational interests (Bercovitch and Gartner 2009: 26). As befitting their status as former heads of government, however, the form of agency associated with their efforts, is quite different: with a high profile personalized dynamic missing in the non-governmental animated variants.

The second debate revolves around the perception of bias with respect to mediators. As the work of Touval and Smith depicted decades ago, the biased condition of the mediator should not in itself pose a barrier to success (Smith 1985; Touval 1985). Indeed, as this type of early revisionist literature pointed out, the perception of bias - especially by the representative of the US - could actually "strength the mediator's leverage, since the party that considers itself favored with the mediator will seek to preserve its good relations" (Touval 1985: 376). Proportionately, "the party that views the mediator as favoring its antagonist will seek to reverse the relationship and win the mediator's sympathy" (Touval 1985).

This image of bias has been recalibrated in the case of voluntary mediators such as former leaders. Even if there was a backlash against the perceived bias vis-à-vis high-level representations of powerful states or from IOs, especially in the classic cases of Kissinger, Haig, or UN good offices in earlier decades, these mediators had other compensatory strengths (Vuković 2011).

With their mix of standing, resources, and interest, the US and the UN, stood out not only apart but above potential other types of mediators. The traditional club-located mediators possessed the unique capability of being able to apply a coercive or directive repertoire. In specific terms, individuals such as Kissinger or Haig , with the ability to supply "carrots" and "sticks", could be manipulative in their application of tools of leverage (Zartman and Touval 1985: 40). The $\mathrm{UN}$, for its part, not only had the advantage of a deep well of experience and organizational resources vis-a-vis mediatory activity but strong claims of legit- 
imacy as a lead actor. As Ahtisaari and Rintakoski contend with considerable accuracy: "Though [the UN's] legitimacy may be strained at times and be different in different parts of the world, there is still no substitute for the moral authority and convening power of the UN... [with a second advantage being that the] UN system, though unwieldly and lacking any real command and control system, is still linked in many ways with the UN Secretariat and the various agencies, funds, and programmes" (Ahtisaari and Rintakoski 2013: 338-9).

Former leaders, whether as individuals and/or as partners in a mediation initiative, possess neither of these advantages. Out of office, with no fixed club, state-based or IO organizational standing and resources, this category of mediators, is at a profound disadvantage in terms of authority and leverage. Above all, it is difficult for these actors to convince the disputants that they can deliver what is taken to be the important ingredients of mediation: credible commitments to ease security concerns (Maoz and Terris 2006; Svensson 2009).

As voluntary mediators, former leaders are much more reliant on a different set of characteristics than the classic types of mediators. Some form of organizational support remains salient, whether in the form of connecting their activities to a wide variety of state-based or institutional partners or through the amplified use of a foundation of their own. At the same time, a prime ingredient returns to the specific attributes of personalized agency. Compensation for a lack of state-based structural leverage or privileged IO standing can potentially come via an intense personal interest in the conflict at the core of the mediatory engagement, an attentiveness that opens up the space for their activities in the first place. It can also come from creativity and flexibility in building networks. As the extended analysis in this article locates, such a fundamental differentiation is at the core of the shift between the classic models and the fluid, complex, but sustained forms of activity exemplified by the experience of mediation in the Venezuela crisis.

\section{RECALIBRATING MEDIATON IN POLARIZED ENVIRONMENTS: THE VENEZUELA CRISIS}

Together with the quality and range of attributes possessed by individual mediators and their networks, it has been the context and especially the combination of space and risks that condition the manner by which various activities play out, that needs to be examined. This is especially so in a case such as the prolonged and bitter Venezuela crisis (Sabatini 2017; Pantoulas and McCoy 2019). Although the Venezuela situation attracted a wide number of potential mediators, the dynamics of mediation in practice did not follow the trajectory of the classic models laid out in the literature. Lead mediators did materialize, but in a highly distinctive fashion than in the illustrations of club or state-cen- 
tric model associated with Kissinger, Haig, or the privileged IO model associated with the UN through activities in earlier decades.

As a host of other potential lead mediators were either found unwilling or unacceptable to this task, the category of former leaders as mediators came to the fore. As rehearsed the role of Jimmy Carter (Democratic Party, 39th president of the United States from 1977 to 1981) and the former Prime Minister of Spain, Jose Luis Rodríguez Zapatero (Spanish Socialist Workers' Party or PSOE, 2004 -11) above all stands out. Such privileging does not mean however that these former leaders acted as solo agents. Equally, the hesitation of other actors to take up a lead role did not mean a complete absence of involvement. Rather it meant that these other more institutionalized actors left responsibility for a sustained primary role to the category of former leaders, due in large part to their greater level of (albeit not complete) autonomy and risk tolerance.

In keeping with the analysis of Ahtisaari and Rintakoski (2013), mediation in terms of the Venezuela crisis became increasingly crowded over time. In the time period of the lead mediation role of Jimmy Carter, there was little or no competition from other potential mediators or their networks. This was especially so during the intensive period of mediation undertaken by Carter and his network from 2002 to 2004 after the attempted coup against President Hugo Chávez Frías in April 2002 (with Chávez retaining power except for this 47hour period from 1999 to his death in 2013). By the time of the lead role taken up by Rodríguez Zapatero, though, the process was far more crowded: with a wide cluster of supportive (and even for short bursts of time, lead) actors during the span of his mediation efforts from 2016 to 2018 with Nicolás Maduro in presidential office (with Maduro taking power in March 2013).

In the concentration in large part on powerful mediators successfully inserted in cases such as the Middle East and the Malvinas/Falklands crisis, the traditional literature plays down the dynamics of the unwilling or unacceptable mediator. Actors such as Kissinger and Haig not only had a massive interest-based incentive to be engaged in these processes, they could not be refused ample space as mediators. In the Venezuela case, these conditions did not hold.

Indeed, one category of potential actors to be eliminated during the Maduro years has been the equivalent of a Kissinger or Haig, a biased but engaged mediator with state-based or club standing, resources and interest. The only possibility of this option was through U.S. Under Secretary for Political Affairs and Special Envoy Tom Shannon. In June 2016, Shannon travelled to Venezuela on the invitation of the Maduro government for talks, after U.S. Secretary of State John Kerry and his Venezuela counterpart, Delcy Rodriguez, agreed to resume bilateral discussions in a private meeting on the sidelines of the OAS General Assembly in Santo Domingo a week earlier (Merco Press 2016). In this process of engagement, Shannon met with President Maduro, Delcy Rodriguez again, and members of civil society. 
While a promising moment given the deep level of animosity and invective between the Maduro regime and the U.S., heightened by sanctions against individuals in and beyond the ruling Partido Socialista Unido de Venezuela, or PSUV (through such measures as the Congress enacted Venezuela Defense of Human Rights and Civil Society Act of 2014) this engagement never shifted to mediation along the lines of the Kissinger or Haig initiatives. Equally, the approach during the span of the Barack Obama presidency was a far cry from the activist Carter-era Camp David model on the Middle East, with the U.S. refraining from ramping up its leverage and/or offering bold reassurance about compensation for losses. If the U.S. was not willing to use potential space, and so take the risks in moving out ahead, however, the opening with Kerry and Shannon at least revealed that the U.S. could step back from acting as a persistent blocker.

As demonstrated in the public narrative of his activities, Shannon was prepared to open a channel of confidence building dialogue (U.S. Department of State 2016). But it was also a confirmation that the U.S. was content to take a secondary role to the mediation process beyond the state-centric model begun by Rodríguez Zapatero, in both his personal capacity and via a wider network of partners. As Shannon explained the motivations: "dialogue is an important way to build bridges; it's an important way to try to create common understandings. But it's also a way for both sides to speak to each other outside of Caracas with international facilitation and with great international interest, with the hope being that this can be used not only to address political differences, but also to create a platform from which both the government and the opposition can ask for help from the international community to address some of the really significant crises that Venezuela faces right now" (U.S. Department of State 2016).

With this gap exposed in traditional forms of leadership, two other institutions had the promise to step in. One of these was the UN. As rehearsed above, the prime traditional candidate from this domain was the UN. Although caught up in a more competitive environment, the UN retained the ingredient lacking in the engagement of most other actors: legitimacy. From this perspective, the words of Pruitt and Johnson decades ago, retain their salience: "The presence of a powerful and legitimate third party allows the party to back down from fixed positions, make concessions, and 'save face.'" (Pruitt and Johnson 1970: 239). Although the UNDP became an active partner in the earlier activities associated with Jimmy Carter, however, the UN ruled itself out both explicitly and consistently from taking a lead role in mediatory activity. As late as February 2019, UNSG Antonio Guterres affirmed that he would not join any initiatives to resolve the political crisis in Venezuela in order to remain neutral (DW 2019).

The other candidate was the Vatican or Holy See, with a robust record of mediation in the Americas including recent efforts on Cuba between the regime 
and the Obama administration, and on Colombia's peace accord. Certainly, there was space available in the Venezuela crisis. The leading anti-chavista coalition since 2009, the Mesa de la Unidad Democrática (MUD) or the Democratic Unity Roundtable, agreed in principle in 2014 to move forward on negotiations to end the conflict if there was a "credible" third party mediator, with the MUD's executive secretary, Ramon Guillermo Aveledo, pushing for this role to be taken on by the Vatican (Aveledo 2014). In this context, the Vatican played a supporting role in the so-called 2014 "National Conference for Peace", which brought together President Maduro, accompanied by several senior politicians in his cabinet and movement, along with opposition leaders Henrique Capriles Radonski, together with different representatives of the MUD. For his own part, Pope Francis after some initial enthusiasm, including sending a letter to the members of the "National Conference for Peace", opening discussions, moved to distance himself from any personal initiative with a backlash from the supporters of the opposition including Venezuela bishops that he was "soft' on the Maduro regime (The Economist 2017).

The Vatican continued to be willing to play a role in Venezuela, most often utilizing a low-key approach albeit with some bursts of leadership. Still these indicatives faced entrenched risks. In October 2016, the new Vatican special envoy to Venezuela, Archbishop Emil Paul Tscherrig, pushed for dialogue to be held on Margarita island (off the northeastern coast of Venezuela), despite suspicions from the opposition (with a number of leaders stating that engagement was not possible after the recall referendum was suspended). And in November (in synch with the initiative by Zapatero, and parallel to the visit by Tom Shannon) Archbishop Claudio María Celli, another special envoy sent by the Vatican as mediator of the conflict, negotiated the participation of the opposition at a dialogue table with the government. Little forward progress, however, was made on concrete progress with regard to the agenda. And by 2017 the Maduro government criticized both the Vatican and the Venezuela bishops for their objections to the government's plan to rewrite the nation's constitution, saying that Pope Francis's advisors had become party to the "violence against the Bolivarian Revolution, Venezuela's legitimate government and Venezuela as a whole" (San Martín 2017).

For a span of time, therefore, the Vatican was reluctant to become the prime mediator albeit with persistent calls to do so. This turned attention to UNASUR, the regional organization the Vatican had worked with in a supportive capacity through 2014 via the "National Conference for Peace". Distinctive from the actors associated with the classic models, UNASUR was willing and accepted (at least initially) as a third party in the Venezuelan crisis, as it had in a wide number of other crisis situations in the Americas (Cevallos and Mouly 2019). As a 2015 report highlights, UNASUR's measure of credibility for many observers was akin to that of the UN: "UNASUR is the only actor recognized both by the government and by its opposition in the Venezuelan internal crisis, 
which had made the bloc the only possible and appropriate mediator. On the one hand, the Venezuelan government refuses any external interference of other non-regional institutions. On the other, the Venezuelan opposition expresses its dissatisfaction in every space available, trying to garner additional support to its cause" (dos Santos 2015: 8).

With this comparative advantage, both in terms of reputation vis-à-vis the U.S. and in terms of willingness vis-à-vis both the US and the UN, UNASUR gained some traction. The April 2014 round table held at the Miraflores Palace was chaired and mediated by Colombian Foreign Minister María Ángela Holguín, Ecuadorian Foreign Minister Ricardo Patiño, and Brazilian Foreign Minister Luiz Alberto Figueiredo, under the auspices of UNASUR. The deeper the process went, though, it was the

constraints not the opportunities that came to the fore. In terms of its operational capabilities, as opposed to its normative legitimacy, UNASUR was held back by a lack of appetite for sustained mediation as opposed to facilitation. The mindset remained one of nudging the disputants forward as opposed to active insertion in the crisis situation. As stated by the UNASUR Director of Political Affairs and Defense Issues, the "agenda must be more of support and monitoring, rather than...action in the sense to try to assign to the Secretariat of UNASUR the resolution capacity. (...) States have sufficient capacity to solve their problems" (dos Santos 2015:18). In the absence of such an activist style of mediation, furthermore, the opposition in particular grew wary of the UNASUR's role, with a downgrading of the organization's image of legitimacy, accusing it of acting like an "insider-partial mediator" with a stake in the outcome, and therefore not legitimate" (dos Santos 2015: 18).

In this vacuum, an accentuated form of voluntary mediation initiatives animated by former leaders moved to fill the gap. At its most developed level, this category of mediators could compensate for their disadvantages in terms of great power leverage and privileged IO legitimacy, through the combination of personal interest and network orientation with a diffuse organizational infrastructure. Moreover, this revised model was not completely novel (Cooper 2014). Although beyond the scope of this article, reference can be made to a number of comparative illustrations that reflect the shift in the classic mediation models. The best-known illustration is the activities of Nelson Mandela in building up the Elders network. But the activities of Martti Ahtisaari the ex-president of Finland are highly relevant as well, as illustrated by his involvement as a mediator in Namibia, Kosovo, and Aceh, Indonesia. In all of these activities beyond the Americas, high profile individual agency was connected to partnerships with a diverse set of other actors, either through the auspices of IOs or through well-funded and sustained personal foundations and NGOs. In other words, the application of this recalibrated model is driven by a single personality, with some measure at least in its public image of a high-profile mediator, balanced by the linkages developed and nurtured through a network approach. 


\section{FORMULATING THE MODEL: MEDIATION BY JIMMY CARTER AND THE CARTER CENTER}

Before analysing in detail, the reconfigured model of mediation as expanded by Rodríguez Zapatero, it is valuable to look closely at the foundations of the approach via the experience of Jimmy Carter, especially in his sustained engagement on the Venezuela crisis both during the 2002-2004 period of the Hugo Chávez presidency and early part of the Nicolás Maduro regime up to 2014. As noted, what imparted an innovative character to Carter's mediatory activities was his ability to combine personalistic animation with networking via his foundation, the Carter Center. While using his insider status as a former U.S. president to gain entry as a mediator, he also utilized space with techniques not commonly associated with state/club-based mediation. Without the need, as a high-profile ex-leader, to conform to standard state-centric or club diplomatic techniques, with an onus on quiet or discreet practices, Carter was willing go public through his initiatives, applying a range of robust methods from positive reinforcement (exhortation) to negative (naming and shaming).

Carter's advance of a recalibrated hybrid model, with blend of personality driven and network-oriented activity came out as well in other dimensions. At one level, Carter's approach was far more individualistic than the leadership of NGOs. His personal strengths were embellished by legacy reputational attributes. In particular, Carter could capitalize on the repository of good will bought from the historic Camp David accords between Israel and Egypt in 1979. At another level, Carter possessed ownership of an embedded organization with the Carter Center in a manner far removed from the bureaucratic structure of NGOs. With the support of the Mediation Centre at the Carter Center, from the late 1980s Carter built up a presence in a wide variety of contexts ranging from Ethiopia, Sudan, Rwanda and the Great Lakes region of Africa, and the settlement of regional disputes more generally (Brinkley 1998; Chambers 1998).

Carter was highly visible as an actor throughout the various mediation efforts he undertook. He was careful, however, not to stage this activity as a oneman show along the lines of the Kissinger and Haig type of classic model. If a highly personalized vehicle, the Carter Center offered space for a wider group of experts such as Jennifer McCoy, and Francisco Diez the mediator that was in charge of the Venezuelan mediatory process via the Carter Center (McCoy and Diez 2011). He was also careful to link his initiatives to the resources of select IOs, without which any constructive outcome would not be possible. This was true of the mediatory work, but it was also true of his role in election monitoring. In 1990, for example, Carter operated in tandem with the UN and OAS in observing the Nicaugua election along with the Council of Freely-Elected Heads of Government. In the 2000-2001 Peru case, Carter worked with the National Democratic Institute for International Affairs (Cooper and Legler 2005, 2006). 
In the earlier stages of his mediatory work, there was considerable space for operations but also risks. Among his ideological/partisan detractors Carter reinforced his image of bias towards the left, by the perception that he was willing to get too close to Chávez in his mediation work on Venezuela. This activity was initiated by Carter's assumption of the role in the election monitoring and democracy promotion effort during the period from the April 2002 coup (toppling momentarily Chávez) to the August 2004 presidential recall referendum. His entry was prompted by an invitation to facilitate a process of national dialogue by Chávez himself (United States Institute of Peace 2011).

Such criticisms of a personalized nature, although persistent, neglect the hybrid nature of Carter's mediation model. To be sure, it has been Carter's individual animation that grabbed attention, above all his high-profile trip to Venezuela in July 2002. But Carter aimed to balance his own out in front efforts with a concerted and networked problem-solving approach. Significantly, the Carter Center joined forces in a "triumvirate" with the OAS and the United Nations Development Program (UNDP) throughout this process of mediation (Cooper and Legler 2005), with OAS Secretary General César Gaviria serving as the facilitator of the dialogue table (with 12 members, six from Chávez's party and six from the Coordinadora Democrática, with the opposition forces) (Olivari 2014). Such balance - supported as well not only by the U.S. but by six countries in the "Group of Friends" (or "Friends of Venezuela") - extended the operational space for the mediatory work still further. While the opposition was wary of Carter's motivations, Chávez was deeply suspicious of the OAS.

In terms of range of activity Carter - and the Carter Center - took on greater risks. If the Center's activities brought kudos, it also brought out a more diverse range of critiques. While Carter was criticized persistently for being too close to Chávez, Jennifer McCoy became the target for attacks by the left. Above all commentators took offence to her testimony before a U.S. subcommittee hearing in 2000, in which Dr. McCoy explicitly placed the Venezuela government in the category of "new, subtler forms of authoritarianism through the electoral option..." (Counterpunch 2004). At the same time, the vehemence of the backlash to Carter, was magnified by the impression from some opposition forces that Carter possessed some influence over Chávez and therefore could nudge him towards solutions that could ease him from office: through a combination of recall referendum and shortening of the presidential term. Thus, with Carter's legitimatization of the result of the August 2004 recall (amid accusations of fraud) there was a strong sense of betrayal (Forero 2004).

Carter was made the target for personalized attacks - notwithstanding the diligent effort as witnessed by the official final reports on the 2012 and 2013 Venezuelan elections by the Carter Center - (Carter Center 2014) - that he favored the Chávez regime. To be sure, this line of critique continued until Carter withdrew from involvement after over an extensive time span of involvement. Although by the time he made his last trip to Venezuela in April 
2014 Carter did not propose to be a mediator, but only to promote dialogue, opposition forces saw him as not only biased, but detrimental in terms of his capacity to legitimize the ongoing maintenance of the Venezuela regime. Revealing in full force the risks associated with personalized initiatives, opposition forces were especially bitter about his endorsement of the "free and fair" electoral process by which Maduro had "won" in April 2013, shortly after Chávez's death. Time and time again, critics refer to Carter's statement at that time that "Venezuela probably has the most excellent voting system that I have ever known" (Cohen 2013).

\section{JOSÉ LUIS RODRÍGUEZ ZAPATERO AND THE EXTENSION OF THE RECALIBRATED MODEL}

Recalibrating the classic models of mediation, through the efforts of Rodríguez Zapatero, was stretched to the limits as the crisis situation in Venezuela became even more intractable in the Maduro years. Under these conditions space for alternative mediatory enagement contracted even further. Whereas Chávez was deeply suspicious of the OAS, to give a prime illustration (Olivari 2014), he and his allies could use the OAS as part of their diplomatic repertoire. With the narrative of stigmatization by the Maduro regime - and its supporters - that the legacy of the organization was simply as a tool for U.S. foreign policy, the OAS was increasingly ruled out in terms of any substantive engagement. Rather the OAS was used as an echo chamber for polarized views. Bolivian President Evo Morales for example stated in August 2016 that the Secretary General of the OAS, Luis Almagro was biased and doesn't defend leftist governments in the region that were under attack: "Where is Almagro? When there's a conspiracy against leftist democratic governments we don't see Almagro, he only appears to defend the right-wing" (Telesur 2016).

The reaction by the Maduro regime was a process of censure and withdrawal from the OAS. As early as 2014 the government excluded María Corina Machado, a prominent civic and political figure, from the Venezuela Congress for allegedly violating the Venezuela constitution by addressing the OAS (at the official invitation of the government of Panama). And under pressure from the invocation of the Democratic Charter, with possible suspension, the Maduro regime announced in April 2017 that it was withdrawing from the OAS (Reuters 2017).

And, in response to this pattern of stigmatization, Almagro tilted the OAS towards the opposition. To give just one illustration, in August 2017 Almagro invited the 33 "parallel" justices of the Venezuela Supreme Court to the organization's headquarters in Washington where he recognized them as "legitimate" and pledged his support. But more broadly Almagro pushed for the invocation of Article 20 of the OAS's Democratic Charter, a provision that referenced the 
"alteration of the constitutional regime that seriously impairs the democratic order" (Venezuelan Analysis 2016a, para. 3).

In terms of networking, this exclusionary culture meant a further shrinking of potential organizational linkages in any mediation effort. Rodríguez Zapatero urged the OAS not to take further action against the Venezuela government so that mediation could play out. Addressing the OAS Permanent Council, at the outset of his own initiative in 2016, the former Spanish prime minister said the dialogue between the Venezuela government and opposition must "address the conflicts and controversies that have clearly existed between branches of government and institutions in Venezuela since the past elections to the National Assembly" (Merco Press 2016, para. 4).

Reference to the OAS is not to suggest though that there weren't other partnership options that Rodríguez Zapatero could take connect with. Both the Vatican and UNASUR could be counted on in terms of support, although at the same time the degree or sustained nature of this support could not be taken too far. Significantly, Brazil's pre-UNASUR initiative around the "Friends of Venezuela" had been not been included as substantive partners with the Carter initiatives (although there was a parallel process and some interaction between them) in 2002-2004. And the 2011 WikiLeaks reveal that Cardinal Antonio Ignacio Velasco, the archbishop of Caracas, provided support not for mediation but for the 2002 coup that briefly overthrew Chávez (O'Shaughnessy 2011).

Such contextual details placed greater pressure onto Rodríguez Zapatero's own personal attributes in order to advance mediation and to forge enhanced links with UNASUR, the Vatican, and other network partners. Akin to Carter, Rodríguez Zapatero had a wealth of experience related to Venezuela. The Carter Center's connections to Venezuela in terms of election monitoring went back to 1998 with respect to the presidential contest in which Hugo Chavez was elected. Subsequently, the Center observed the referendum that approved a new constitution and then a new election in July 2000 in which Chávez was re-elected. Rodríguez Zapatero's own exposure stretched back formally to 2005 when as prime minister he made a controversial trip to Venezuela, with the main material takeaway being a $\$ 1$ billion arms deal.

Inevitably this record cultivated an image that Zapatero was biased towards Chavismo and the government: tied together by a socialist affinity. Such an impression, however, was tempered by a number of other factors. For one thing, Rodríguez Zapatero was not immune from distancing himself from Chávez, even in a highly public setting. At the 2007 Ibero-American Summit, in most dramatic fashion, Rodríguez Zapatero turned on the Venezuelan president, after he was persistently interrupted by Chávez for defending the reputation of his conservative predecessor against charges that he had supported the 2002 coup in Venezuela (Reuters 2007). 
Arguably, even more importantly, Rodríguez Zapatero had some close contact with opposition leaders. Not only did some of the MUD have an ideological affinity with Rodríguez Zapatero's social democratic background, but this positive image was reinforced by Rodríguez Zapatero's involvement with monitoring of the legislative assembly elections in 2015 (Cevallos and Mouly 2019). Indeed, Rodríguez Zapatero was invited to re-engage in the Venezuela crisis by Timoteo Zambrano, former member of Acción Democrática and Un Nuevo Tiempo (social democratic), with both parties' belonging to the MUD (Villegas 2016). What is more, he built up further good will with Lilian Tintori, the wife of jailed Venezuelan opposition leader Leopoldo Lopez, through the process of Lopez's release from Ramo Verde prison to house arrest in July 2017 (Información 2017).

To these valuable personal characteristics was added Rodríguez Zapatero's ability to nurture components of an elaborate networked orientated strategy. As rehearsed, one important ingredient in this network was UNASUR. UNASUR had long and abiding interest in the Venezuela crisis, with potential for mediating with the Maduro regime since 2014. Despite attempts, especially by the Maduro forces, to pull it into a more active role beyond its role at the 2014 "National Conference for Peace", UNASUR held back. The UNASUR Council of Ministers of Foreign Affairs did visit Venezuela in 2014, but with only with a cautious approach. And although in February 2015 Maduro pressed Ecuadorian President Rafael Correa, UNASUR's president pro tempore, to serve as "a protective shield for peace and democracy in Venezuela" UNASUR refrained from taking a lead role - preferring instead to support Rodríguez Zapatero's mediation efforts (Meza 2015).

Facilitated by former Colombian President and UNASUR Secretary General Ernesto Samper, Zapatero's initiative was both similar and different to Carter's. Unlike Carter, Rodríguez Zapatero cannot be classified as a hyper-empowered individual, with a personal reputation that provides him elevated status as a mediator. Nor, had Rodríguez Zapatero akin to Carter, become a professional mediator. Rodriguez Zapatero didn't have the same range of experience. Nor had Rodríguez Zapatero built up organizational capacity via a foundation or NGO of his own.

These gaps placed a considerable burden on both his own powers of persuasion and the organizational support of his network associations. Using the space available, Rodríguez Zapatero navigated this process in an impressive manner. The imitative exhibited excellent team work between Rodríguez Zapatero and other reputable former leaders from within the region, above all the support from the outset by Leonel Fernández of the Dominican Republic and Martin Torrijos of Panama. All three had access to a variety of actors engaged in the Venezuela situation, although as other actors' perceptions of bias came through. Leonel Fernández was criticized by some for being close to the Maduro regime, charges of bias that were fuelled by the fact that Fernández not only agreed to serve on a sub-committee designed to alleviate 
the economic crisis but met directly with President Maduro. As the Venezuela foreign ministry put it: "President Nicolas Maduro met with ex-president Leonel Fernández! They revised an agenda to defeat the economic war" (Venezuelan Analysis 2016b, para. 8).

No less than the Carter approach, the Rodríguez Zapatero initiative was persistent, with elements of shuttle diplomacy. It refrained from any of the tough pressure tactics associated with the OAS. It was content to play a patient game, working on the agenda, and sites to work, and pushing on, despite a number of setbacks. Rodríguez Zapatero's group held at least 20 meetings with Venezuela officials subsequent to May 2016 (Sullivan 2017).

If some considerable positives stood out, not the least the willingness to leverage space and take risks, so did the formidable constraints. Rodríguez Zapatero did not have the advantages of the experienced team attached to the Carter Center. Nor did he work to build up this component from his trip before the Venezuela parliamentary elections in December 2015 to the start of his initiative in May 2016. There was also some lack of clarity of the mandate. Although Samper originally announced that Rodríguez Zapatero, Fernández and Torrijos would be part of a "Truth Commission", Rodríguez Zapatero's initiative did not operate in this framework, as the opposition forces considered this instrument to be a device manufactured by the Maduro government (The Diplomat 2016). What Rodríguez Zapatero and the other former leaders termed it was as a "national dialogue".

Under these conditions the process was one that featured frequent starts and stops. Exploratory talks were held behind closed doors in the Dominican Republic in May 2016, led by Rodríguez Zapatero, Fernández and Torrijos by invitation from UNASUR. While the government was represented by Foreign Minister Delcy Rodriguez, congressman Elias Jaua and Caracas Mayor Jorge Rodriguez, MUD remained at arm's length from the process concerned that they could be a trap to temper pressure, pry apart the opposition, and buy time for the government. Jesús Torrealba, executive secretary of the opposition alliance (active in a number of other efforts including the Vatican led October 2016 initiative), went to great care to say that there were no face-to-face meetings between the two sides -and that they exchanged messages only through the former leaders (Associated Press 2016).

Buttressed by the presence of the Vatican, however, the initiative gained some momentum. While still highly contested a process, the two sides at least showed some willingness to take part in a form of engagement: with Maduro and his representatives meeting for the first time in two years on October 30,2016, with a number of opposition leaders, including Democratic Unity coalition Secretary-General Jesús Torrealba and opposition Governor (and 2018 presidential candidate) Henri Falcon. As the Vatican special envoy, Monsignor Claudio Maria Celli, stated: "I think it's very positive that the government delegation and 
the opposition have met, have spoken, facing delicate and important topics for the life of the country... One of the ex-presidents used the word 'miracle' that the two delegations talk and do so in a respectful, attentive manner, because that is unquestionable" (Oré and Buitrago 2016).

Once again, though, expectations were dampened. In contrast to the May 2016 dynamics, during the latter stage it was the government that proved reluctant to continue. For, by early November, the Maduro delegation stopped going to the technical table meetings, under a great deal of uncertainty. While some opposition forces were sympathetic to the former Spanish prime minister (on the premise that the government was misleading him) others began to criticize Rodríguez Zapatero for not maintaining the process: a backlash that gained momentum and became more personalized over time. By December the opposition declared the dialogue "dead", although significantly the way was kept open for a renewal, with Torrealba stating: "We will maintain our relationship only with the mediators and especially with the Vatican, in order to follow up on compliance with what has already been agreed" (Silvestre 2016).

Notwithstanding this type of continued setback, then, the initiative continued to morph through further stages from 2016 to 2018. Under the auspices of the Dominican President, Danilo Medina, along with Rodríguez Zapatero, the mediation process sprung back into life. In terms of deepening, the process grew to encompass to active participation with three opposition representatives from the Primero Justicia, Voluntad Popular and Acción Democrática taking place. Foreign Minister Delcy Rodriguez took part along with two top officials in the ruling socialist party. By the end of the still highly contested process, moreover, there had at least been direct engagement between

Rodríguez Zapatero and key figures, notably Jorge Rodríguez, Minister of Communication and Information, and Julio Borges, former president of the National Assembly and coordinator of the party of Henrique Capriles, Primero Justicia (El País 2018) - both firm opponents of earlier forms of engagement. In terms of widening, the talks had the accompaniment of international observers elected by both the opposition and the government. The opposition designated Chile and Mexico, and the government selected Bolivia, Nicaragua, and Saint Vincent and the Grenadines.

Still, amid all of this intense if uneven effort, the process unravelled with the deterioration of the situation on the ground in Venezuela: including the death of the rebel ex-policeman Oscar Perez, and the unilateral decision of the National Constituent Assembly to advance the presidential Elections. Opposition representatives also demanded a lift on the current ban stopping their own main leaders from running in the election: Henrique Capriles and Leopoldo López. Dominican leader Danilo Medina said that talks have entered "an indefinite recess" after the opposition refused to add their name to a draft document signed by Nicolás Maduro, on the grounds that it was insufficient. While the government blamed 
the U.S., the opposition's refusal to sign an agreement (although pressed to do so, by Rodríguez Zapatero) was based on the argument that it did not contain water-tight electoral guarantees (Pantoulas and McCoy 2019).

\section{CONCLUSIONS: SPACE AND RISKS OF THE RECALIBRATED MODEL}

The recalibration from the classic mediation models places a great deal of onus on the attributes of individual actors not firmly positioned as representatives of either a powerful state or a privileged IO. As witnessed by the Venezuela crisis, there is space available for this type of voluntary mediator. Indeed, in the absence of the willingness or capability of traditional actors such as the US or the UN to take on a lead role, the use of the voluntary option is the primary one open for sustained initiatives, as witnessed by the prominent role by Jimmy Carter and José Luis Rodríguez Zapatero, both prominent former leaders with a deep and abiding interest in the Venezuela crisis.

To highlight this personalistic component is not to exaggerate this component in the recalibrated model. Voluntary mediation did not mean a form of complete autonomous agency on the part of Carter or Rodríguez Zapatero. Certainly, these ex-leaders cannot be classified as freelance actors. Ingrained in their initiatives was a networked component that must be privileged through the process of engagement. In Carter's case this came though connections not only via his own foundation, but through linkages with the OAS and UNDP. During the work of the dialogue table, OAS Secretary General César Gaviria stepped out in front as facilitator. Without a foundation of his own, Rodríguez Zapatero was even more heavily connected to other partners: UNASUR and the Vatican, the Dominican leader Danilo Medina, and former presidents from the Dominican Republic Leonel Fernández and Martin Torrijos of Panama.

Yet, if the space was shared, the hybridity of personality and network driven activity risked imbalance. Whereas the OAS came in and out of the mediation efforts, Carter's role was comparatively consistent, stretching out over decades. Although there was no apparent tension between these components, Carter's own activities stood out as the most prominent attribute of the recalibrated model. The multiplicity associated with the Rodriguez Zapatero initiatives also featured a lack of visible competition, with a tilt towards a focus on Rodriguez Zapatero own attributes. UNASUR and the Vatican along with other individuals came in and out of initiatives, while Rodríguez Zapatero's pattern of engagement were sustained over time.

Such a high profile in the recalibrated model for individual mediators inevitably carried the potential for high rewards but also for controversy. Breakthroughs via voluntary mediation- where a disproportionate burden of responsibility is placed on a single individual as opposed to a representative of the U.S. or the 
$\mathrm{UN}$ in the classic model - were very difficult and at key points of the process provided an excuse for breaking off negotiations. While Carter and Rodríguez Zapatero were in the forefront of a team effort building and maintaining the mediation process, they carried as individuals a disproportionate degree of the public blame for failure.

With his far more varied record of engagement - punctuated by enormous success (his role in Cuba stands out) (McCoy 2015), as well as failure - Carter had some buffeting from the inability of his efforts to contribute to a peaceful settlement on Venezuela. Rodríguez Zapatero was far less cushioned. The intensity of the process of Rodríguez Zapatero's pattern of activity - in his only major initiative of mediation activity - meant that he was far less insulated in reputational terms. Through to the culmination of his engagement, Rodríguez Zapatero's motivations were explicitly impugned, with charges (amid accusation that he asked the opposition to accept Maduro's demands) that he had become the regime's messenger, not a mediator" (El País 2018). Such a negative interpretation of Rodríguez Zapatero's engagement could, to be sure, be rebutted, especially given the polarized conditions featured in the Venezuela crisis. Faced with this type of personal stigmatization, close to two hundred politicians, intellectuals, professors and diplomats signing a manifesto in which they defended Rodríguez Zapatero's efforts (El Plural 2018).

Yet, such a serious debate necessitates a re-opening for analytical reconsideration, concerning the value of the shift away from the classical models of mediation. As the Venezuela crisis reveals, the primary role of the traditional mediators was absent, with both the U.S. and the UN missing in action. Moreover, even if these actors possessed the will to engage, under polarized conditions they lacked the individual agents and/or the networking capacities required. While not as strategically well-designed as the literature argues is necessary for a positive outcome, the ingredients combined in the recalibrated model put together by Jimmy Carter and José Luis Rodríguez Zapatero offered at least the possibility of success: most notably due to the impressive individual features and the capability of working in a networked fashion (Ahtisaari and Rintakoski 2013: 340). As Ahtisaari and Rintakoski conclude however: "Different mediation styles and approaches are appropriate in different situations depending on the conflict situation and the profile and experience of the mediator" (Ahtisaari and Rintakoski 2013: 341). Any further exploration of the recalibrated model of mediation, with the utilization of a hybrid personality-network driven initiative, thus needs careful deliberation. No mediator, especially in such a polarized environment as in the Venezuela crisis, will be viewed as unbiased. That said, voluntary mediators such as Carter and Rodríguez Zapatero are more susceptible to other hazards because of the contradictions in their fundamental approach, Because of their identity as individuals and their skills in partnership, the recalibrated model fills space and raises expectations. Nonetheless, the actors at the core of this recalibrated model lack the means of leverage re- 
quired to turn process into delivery. Personal attributes and flexibility of mode of operation allows full engagement. But in the absence of the active backing of either a powerful state or privileged $\mathrm{IO}$ - the vital ingredients located in the classical models of state-based or UN animated mediation - it is the risks not the innovative qualities that obtrude.

\section{REFERENCES}

Ahtisaari, Martti and Kristiina Rintakoski. 2013. "Mediation." In Oxford Handbook on Modern Diplomacy, edited by Andrew F. Cooper, Jorge Heine and Ramesh Thakur. Oxford: Oxford University Press, 337-351.

Associated Press. 2016, 28 May. "Ex-World Leaders Meet With Venezuelan Officials and Opposition to End Standoff." Retrieved from https:/ /www.theguardian.com/world/2016/ may/28/venezuela-government-standoff-nicolas-maduro-hugo-chavez

Associated Press. 2017, 8 July. "Venezuelan Opposition Leader Leopoldo Lopez Released From Prison and Placed Under House Arrest." Retrieved from http:/ /www.latimes. com/world/la-fg-lopez-house-arrest-20170708-story.html

Associated Press. 2019, 31 January. "U.S. Rejects Mediation Offers on Venezuela Crisis." Retrieved from https://www.local10.com/news/venezuela/us-rejects-mediation-offers-on-venezuela-crisis

Aveledo, Ramon Guillermo, 2014, 9 April. Letter to the New York Times. "Who Takes the Blame for Venezuela's Crisis?" Retrieved from https://www.nytimes.com/2014/04/04/ opinion/who-takes-the-blame-for-venezuelas-crisis.html

Bartoli Andrea. 1999. "Mediating Peace in Mozambique: The Role of the Community of Sant'Egidi." In Herding Cats: Multiparty Mediation in a Complex World, edited by Chester A. Crocker, Fen Osler Hampson and Pamela Aall. Washington: Institute of Peace Press, 245-274.

Bercovitch, Jacob. 1996. Resolving International Conflict: The theory and Practice of Mediation. Boulder, CO: Lynne Rienner.

Bercovitch, Jacob and Gartner, Scott S. 2009. International Conflict Management: New Approaches and Findings. Routledge: London.

Brinkley, Douglas. 1998. The Unfinished Presidency. New York: Viking Press.

Carter Center, 2014, 21 May. "Carter Center Releases Final Report on Venezuela's April 2013 Presidential Elections." Retrieved from https://www.cartercenter.org/news/pr/venezuela-052214.html

Cevallos, Pryanka Peñafiel and Cécile Mouly. 2019. "UNASUR in Venezuela: Mediation, Bias and Legitimacy." Contexto Internacional 41(3): 579-598. Retrieved from http:/ /dx.doi. org/10.1590/s0102-

Chambers, John Whiteclay. 1998. "Jimmy Carter's Public Policy Ex-Presidency." Political Science Quarterly 113(3): 405-425.

Cohen, Ben. 2013, 20 June. "Jimmy Carter Gives Seal of Approval to Venezuela Election." Commentary. Retrieved from https://www.commentarymagazine.com/foreign-policy/jimmy-carter-gives-seal-of-approval-to-venezuela-election/

Cooper Andrew F. 2004. "The Making of the Inter-Democratic Charter: A Case of Complex Multilateralism." International Studies Perspectives 5(1): 90-121.

Cooper, Andrew F. 2014. Diplomatic Afterlives. Cambridge: Polity.

Cooper Andrew F. and Thomas Legler. 2005. "A Tale of Two Mesas: The OAS Defense of Democracy in Peru and Venezuela." Global Governance 11(3): 425-444.

Cooper Andrew F. and Thomas Legler. 2006. Intervention without Intervening? OAS and Democracy in the Americas. New York: Palgrave Macmillan. 
Counterpunch. 2004, 14 August. "Can She be an Impartial Observer of Venezuela's Referendum?" Retrieved from https://www.counterpunch.org/2004/08/14/ can-she-be-an-impartial-observer-of-venezuela-s-referendum/

Crocker, Chester A., Fen Osler Hampson and Pamela Aall. 1999. Herding Cats: Multiparty Mediation in a Complex World. Washington: United States Institute of Peace Press.

dos Santos, Camila. 2015. “UNASUR's Role as a Mediator: The Venezuelan Case." Policy Brief 5(9): 1-20. Rio de Janeiro: BRICS Policy Center.

DW. 2019, 4 February. "UN Rejects Call to Join Venezuela Mediation Efforts." Retrieved from https://www.dw.com/en/un-rejects-call-to-join-venezuela-mediation-efforts / a-47358766

El País. 2018, 8 February. "Former Spanish PM sides with Venezuela's Maduro over elections." Retrieved from https://elpais.com/elpais/2018/02/08/inenglish/1518100240_457096.html

El Plural. 2018, 14 February. "Más de 200 personalidades reaccionan ante el virulento ataque de 'El País' contra Zapatero." Retrieved from https://www.elplural.com/politica/mas-de-200-personalidades-reaccionan-ante-el-virulento-ataque-de-el-pais-contra-zapatero_119679102

Forero, Juan. 2004, 16 August. "Chávez Is Declared the Winner in Venezuela Referendum." New York Times. Retrieved from https://www.nytimes.com/2004/08/16/internatio$\mathrm{nal} /$ americas/chvez-is-declared-the-winner-in-venezuela-referendum.html

Goshko, John M. 1982, April 7. “Haig Takes Up Role of Crisis Mediator.” Washington Post. Retrieved from https://www.washingtonpost.com/archive/politics/1982/04/07/ haig-takes-up-role-of-crisis-mediator/562d29ab-918e-4455-bf6c-dcbfa374a5e0 /

Heine, Jorge. 2013. "From Club to Network Diplomacy." In Oxford Handbook on Modern Diplomacy, edited by Andrew F. Cooper, Jorge Heine and Ramesh Thakur. Oxford: Oxford University Press, 54-69.

Información. 2017, 10 July. "Lilian Tintori agradece a Zapatero su papel en la liberación de Leopoldo López." Retrieved from https://www.diarioinformacion.com/internacional/2017/07/10/lilian-tintori-agradece-zapatero-papel/1915485.html

Maoz, Zeev and Lesley Terris 2006. "Credibility and Strategy in International Mediation." International Interactions 32(4): 409-440.

McCoy, Jennifer. 2015, 14 August. "Jimmy Carter in Cuba." The Conversation. Retrieved from http:/ / theconversation.com/jimmy-carter-in-cuba-46109

McCoy, Jennifer and Francisco Diez. 2011. International Mediation in Venezuela. Washington DC, United States Institute of Peace.

Merco Press. 2016, 22 June. "OAS listens to mediators' appeal for government/opposition dialogue in Venezuela." Retrieved from https://en.mercopress.com/2016/06/22/ oas-listens-to-mediators-appeal-for-government-opposition-dialogue-in-venezuela

Meza, Alfredo. 2015, 5 February. "Venezuelan president asks Unasur to mediate in relations with US." El País. Retrieved from https://elpais.com/elpais/2015/02/05/inenglish/1423156135_290868.html

Olivari, Denisse Rodriguez. 2014. The Role of the Organization of American States in Promoting Democracy. International Institute for Democracy and Electoral Assistance. Stockholm: International IDEA. Retrieved from https://www.idea.int/sites/default/ files/publications/the-role-of-the-organization-of-american-states-in-promoting-democracy.pdf

Oré, Diego and Deisy Buitrago. 2016, 11 November. "Venezuela government and opposition talk, expectations low." Reuters. Retrieved from https://www.reuters.com/article/ us-venezuela-politics/venezuela-government-and-opposition-

O'Shaughnessy, Hugh. 2011, 30 June. "Priests, plots ... and Hugo Chávez." The Guardian. Retrieved from https://www.theguardian.com/commentisfree/belief/2011/jun/30/ venezuela-chavez-catholic-bishops

Pantoulas, Dimitris and McCoy, Jennifer. 2019. "Venezuela: an unstable equilibrium." Revista de Ciencia Política 39(2): 391-408. 
Pruitt, Dean G. 1981. "Kissinger as a Traditional Mediator with Power." In Dynamics of Third Party Intervention in the Middle East, edited by Jeffrey Z. Rubin. New York: Praeger.

Pruitt, Dean G. and Douglas F. Johnson. 1970. "Mediation as an aid to face saving in negotiation." Journal of Personality and Social Psychology 14 (3): 239-246.

Reuters. 2007, 15 November. "Chávez Threatens to Reconsider Venezuela's Ties with Spain." Retrieved from https://www.nytimes.com/2007/11/15/world/americas/15venez. html

Reuters. 2016, 28 May. "Venezuela government, opposition meet with mediators in Dominican Republic." Retrieved from https://www.reuters.com/article/us-venezuela-politics/venezuela-government-opposition-meet-with-mediators-in-dominican-republic-idUSKCNOYJOGT

Reuters. 2017, 26 April. "Venezuela to withdraw from OAS, denounces campaign by Washington." Retrieved from https://www.reuters.com/article/us-venezuela-oas/venezuela-to-withdraw-from-oas-denounces-campaign-by-washington-idUSKBN17S330

Sabatini, Christopher. 2017, 7 July. "Mediation in Venezuela Is Doomed to Fail Foreign Affairs." Retrieved from https://www.foreignaffairs.com/articles/venezuela/2017-07-07/ mediation-venezuela-doomed-fail

San Martín, Inés. 2017, 5 August. “Venezuela's Maduro says line of Vatican's top diplomat is 'regrettable.". Retrieved from https://cruxnow.com/global-church/2017/08/05/ venezuelas-maduro-says-line-vaticans-top-diplomat-pathetic/

Silvestre, Senabri. 2016, 9 December. "Venezuela dialogue 'dead' after opposition leaves table." Anadolu Ajansı. Retrieved from https://www.aa.com.tr/en/americas/venezuela-dialogue-dead-after-opposition-leaves-table/702562

Smith, William P. 1985. "Effectiveness of the biased mediator." Negotiation Journal 1(4): 363372.

Sullivan, Mark P. 2017, 23 January. “Venezuela: Issues for Congress, 2013-2016." Congressional Research Service. Retrieved from https://fas.org/sgp/crs/row/R43239.pdf

Svensson, Isak. 2009. "Guaranteeing Peace: The Credibility of Third-Party Mediators in Civil Wars." In International Conflict Mediation: New Approaches and Findings, edited by Jacob Bercovitch and Scott Gartner. London: Routledge.

Telesur. 2016, 30 August. "Where is Almagro? When there's a conspiracy against leftist democratic governments we don't see Almagro, he only appears to defend the right-wing." Retrieved from https://www.telesurenglish.net/news/Evo-Morales-Says-the-OASIs-Biased-Against-Latin-Americas-Left-20160830-0030.html

The Diplomat, 2016, 18 May. "Zapatero visits Venezuela to make sure Government and opposition dialogue." Retrieved from https://thediplomatinspain.com/en/2016/05/zapatero-visits-venezuela-to-make-sure-government-and-opposition-dialogue/

The Economist. 2017, 11 June. "Stop being soft on our despot Venzuelas' bishops tell francis." Retrieved from https://www.economist.com/erasmus/2017/06/11/stop-beingsoft-on-our-despot-venezuelas-bishops-tell-francis

Touval, Saadia. 1985. "The Context of Mediation." Negotiation Journal 1(4): 373-378.

Touval, Saadia and William Zartman. 1985. International mediation in theory and practice. Westview Press with the Foreign Policy Institute, School of Advanced International Studies. Baltimore: Johns Hopkins University.

United Nations. 2011. Department of Political Affairs, Mediation Startup Guidelines. Retrieved from https://peacemaker.un.org/sites/peacemaker.un.org/files/MediationStartupGuidalines_UNDPA2011.pdf

U.S. Department of State. 2016, 24 June. "Special Briefing, Under Secretary for Political Affairs Tom Shannon on Venezuela." Retrieved from https://2009-2017.state.gov/r/ $\mathrm{pa} / \mathrm{prs} / \mathrm{ps} / 2016 / 06 / 259037 . \mathrm{htm}$

United States Institute of Peace. 2011. "International Mediation in Venezuela". Retrieved from https://www.usip.org/publications/international-mediation-venezuela

Venezuelan Analysis. 2016a, 31 May. "OAS Secretary General Invokes Democratic Charter against Venezuela." Retrieved from https://venezuelanalysis.com/news/12001 
Venezuelan Analysis. 2016b, 23 May. “UNASUR Economic Team Gets to Work in Venezuela, UN Urges Dialogue." Retrieved from https://venezuelanalysis.com/news/11988

Villegas, Vladimir. 2016, 3 July. Interview of Zapatero [video]. YouTube. Retrieved from https:/ / www.youtube.com/watch?v=tlI03rNXpA0

Vuković, Siniša. 2011. "Strategies and Bias in International Mediation." Cooperation and Conflict 46(1): 113-119.

Received: September 4, 2019

Accepted: February 2, 2020

Andrew F. Cooper.Professor at the Balsillie School of International Affairs and the Department of Political Science, University of Waterloo, Canada. From 2003 to 2010 he was the Associate Director and Distinguished Fellow of the Centre for International Governance Innovation (CIGI). He is the author/co-author of 12 books, including most recently BRICS VSI (OUP, 2016); Diplomatic Afterlives (Polity, 2014); Internet Gambling Offshore: Caribbean Struggles over Casino Capitalism (Palgrave, 2011); and Intervention without Intervening? OAS and Democracy in the Americas (Palgrave Macmillan, 2006). He is also the co-editor of the Oxford Handbook of Modern Diplomacy (Oxford University Press, 2013). In 2019 he received the Distinguished Scholar Award from the Diplomacy Section of the International Studies Association. Correo electrónico: acooper@uwaterloo.ca 
